\title{
Research on Psychological Evaluation System of Domestic Violence Victims-Based on Evaluation Model of Three-dimensional Screening by Myer
}

\author{
Jian $\mathrm{Lin}^{1}$, Xiaodong $\mathrm{Wu}^{1}$, Sixin $\mathrm{Chen}^{1}$, Yubing $\mathrm{Hu}^{1}$, Changlin Liang ${ }^{1}$ \\ Chongqing, Police College, Chongqing, 401331, China
}

Keywords: domestic violence, psychological evaluation, evaluation model of three-dimensional screening by Myer

\begin{abstract}
Family violence occurs among family members, by beating, binding, confinement, mutilation or other means of family members to lead to the injury and destructionfrom the aspects of body, spirit and others. Crisis intervention should try to compare the current status of the current situation with the level of pre-crisis functions to determine the extent of the emotional, cognitive, and behavioral level. Three dimensional evaluation model makes use of the emotional, cognitive and behavioral responses to understand the evaluation process.
\end{abstract}

\section{Evaluation model of three-dimensional screening by Myer}

Myer's three-dimensional evaluation model of proposed by Myer in Pittsburgh of Pennsylvania. He believes that the crisis intervention should be used to compare the caller function level and the current crisis before as far as possible, in order to determine the crisis after the patient emotional, cognitive and behavioral functional level damage degree. He put forward a three dimensional evaluation model of emotional cognitive behavior of crisis intervention, using the three core components of emotion, cognition and behavioral response to understand the evaluation process. This evaluation model is considered to be a simple, rapid and effective evaluation system, from the three functions of patient's cognition and emotion and behaviors of the assessment of the patient's functional level will determine the current crisis intervention strategy and the choice of intervention after consulting in degree.

\section{Crisis intervention of Classified assessment scale}

Briefly confirm and describe the crisis event.

Briefly confirm and describe the emotion performance at present. (If there are several kinds of emotions, please prioritize them.)

Anger and hostility:

Fear and anxiety:.

Depression and sorrow: 
Table 1. Assessment scale of emotion extent

\begin{tabular}{|c|c|c|c|c|c|}
\hline 1 & 3 & 5 & 6 & 8 & 10 \\
\hline No harm & Little harm & Light harm & Medium harm & $\begin{array}{l}\text { Significant } \\
\text { harm }\end{array}$ & $\begin{array}{l}\text { Serious } \\
\text { harm }\end{array}$ \\
\hline $\begin{array}{l}\text { Emotional } \\
\text { state } \\
\text { stability, } \\
\text { emotional } \\
\text { expression } \\
\text { of the } \\
\text { daily } \\
\text { activities. }\end{array}$ & $\begin{array}{l}\text { The emotional } \\
\text { response to the } \\
\text { environment is } \\
\text { appropriate, } \\
\text { the } \\
\text { environment } \\
\text { changes only a } \\
\text { temporary } \\
\text { negative } \\
\text { emotion, not } \\
\text { strong, } \\
\text { emotions can } \\
\text { be completely } \\
\text { controlled by } \\
\text { the help. }\end{array}$ & $\begin{array}{l}\text { The emotional } \\
\text { response to the } \\
\text { environment is } \\
\text { appropriate, } \\
\text { but for a longer } \\
\text { period of time } \\
\text { the negative } \\
\text { emotions of } \\
\text { environmental } \\
\text { change, the } \\
\text { caller can } \\
\text { realize the } \\
\text { need for self- } \\
\text { control. }\end{array}$ & $\begin{array}{l}\text { The emotion } \\
\text { has the contact } \\
\text { to the } \\
\text { environmental } \\
\text { response, often } \\
\text { displays the } \\
\text { negative } \\
\text { sentiment, has } \\
\text { the intense } \\
\text { emotion } \\
\text { fluctuation to } \\
\text { the } \\
\text { environment } \\
\text { change, } \\
\text { although the } \\
\text { emotion state } \\
\text { is stable, but } \\
\text { needs to } \\
\text { control the } \\
\text { mood } \\
\text { diligently. }\end{array}$ & $\begin{array}{l}\text { Negative } \\
\text { emotional } \\
\text { experience is } \\
\text { obviously } \\
\text { beyond the } \\
\text { influence of } \\
\text { the } \\
\text { environment, } \\
\text { the } \\
\text { environment } \\
\text { and the } \\
\text { environment is } \\
\text { not } \\
\text { coordinated, } \\
\text { mood swings, } \\
\text { the caller is } \\
\text { aware of } \\
\text { negative } \\
\text { emotions, but } \\
\text { cannot control. }\end{array}$ & $\begin{array}{l}\text { Total } \\
\text { loss or } \\
\text { extreme } \\
\text { grief }\end{array}$ \\
\hline
\end{tabular}

If there is violation, threat or loss, please describe briefly. (If there are several kinds of cognition, please prioritize them.)

Physiology and environment aspect (food, water, safety, place)

Violation: Threat: Loss:

Psychological environment (Self-awareness, emotional expression, identity)

Violation: Threat: Loss:

Social relationship aspect (family, friends, colleagues)

Violation: Threat: Loss:

Morality/spirit aspect (individual attitude, value, faith)

Violation: Threat: Loss: 
Table 2. Assessment scale of cognition extent

\begin{tabular}{|c|c|c|c|c|c|}
\hline 1 & 3 & 5 & 7 & 8 & 10 \\
\hline No harm & Little harm & $\begin{array}{l}\text { Light } \\
\text { harm }\end{array}$ & $\begin{array}{l}\text { Medium } \\
\text { harm }\end{array}$ & $\begin{array}{l}\text { Significant } \\
\text { harm }\end{array}$ & $\begin{array}{l}\text { Serious } \\
\text { harm }\end{array}$ \\
\hline $\begin{array}{l}\text { The ability to } \\
\text { focus, solve } \\
\text { problems and } \\
\text { make } \\
\text { decisions is } \\
\text { normal, and } \\
\text { the } \\
\text { understanding } \\
\text { and } \\
\text { perception of } \\
\text { the crisis is } \\
\text { consistent } \\
\text { with the } \\
\text { actual } \\
\text { situation }\end{array}$ & $\begin{array}{l}\text { The } \\
\text { thinking of } \\
\text { the help is } \\
\text { concentrated } \\
\text { on the crisis, } \\
\text { but the mind } \\
\text { can be } \\
\text { controlled } \\
\text { by the will, } \\
\text { the ability to } \\
\text { solve } \\
\text { problems } \\
\text { and make } \\
\text { decisions is } \\
\text { slightly } \\
\text { damaged. }\end{array}$ & $\begin{array}{l}\text { The } \\
\text { occasional } \\
\text { attention } \\
\text { is not } \\
\text { focused, it } \\
\text { is more } \\
\text { difficult to } \\
\text { control the } \\
\text { thinking } \\
\text { of the } \\
\text { crisis, the } \\
\text { ability to } \\
\text { solve } \\
\text { problems } \\
\text { and make } \\
\text { decisions, } \\
\text { the crisis } \\
\text { of the } \\
\text { cognitive } \\
\text { and } \\
\text { perception } \\
\text { of the } \\
\text { event and } \\
\text { the actual } \\
\text { situation is } \\
\text { expected } \\
\text { to have } \\
\text { some } \\
\text { deviations. }\end{array}$ & $\begin{array}{l}\text { Don't always } \\
\text { focus more } \\
\text { attention, } \\
\text { consider the } \\
\text { crisis and to } \\
\text { extricate } \\
\text { themselves, } \\
\text { problem } \\
\text { solving and } \\
\text { decision } \\
\text { making } \\
\text { ability due to } \\
\text { the forced } \\
\text { thinking, self- } \\
\text { doubt and } \\
\text { hesitation two } \\
\text { affected, are } \\
\text { obviously } \\
\text { different on } \\
\text { the } \\
\text { understanding } \\
\text { and } \\
\text { perception of } \\
\text { crisis and } \\
\text { reality. }\end{array}$ & $\begin{array}{l}\text { Indulge in } \\
\text { the event } \\
\text { of a crisis } \\
\text { due to the } \\
\text { forced } \\
\text { thinking, } \\
\text { thinking, } \\
\text { self-doubt } \\
\text { and } \\
\text { hesitation } \\
\text { and } \\
\text { influence } \\
\text { patient } \\
\text { ability to } \\
\text { solve } \\
\text { problems } \\
\text { and make } \\
\text { decisions, } \\
\text { on the } \\
\text { cognition } \\
\text { and } \\
\text { perception } \\
\text { of crisis } \\
\text { events and } \\
\text { reality may } \\
\text { have } \\
\text { substantial } \\
\text { differences. }\end{array}$ & $\begin{array}{l}\text { In addition to } \\
\text { the crisis, } \\
\text { unable to } \\
\text { concentrate, } \\
\text { affected by } \\
\text { forced } \\
\text { thinking, self- } \\
\text { doubt and } \\
\text { hesitation, } \\
\text { loss of } \\
\text { problem } \\
\text { solving and } \\
\text { decision } \\
\text { making skills, } \\
\text { have } \\
\text { significant } \\
\text { differences in } \\
\text { understanding } \\
\text { and } \\
\text { perception of } \\
\text { crisis and } \\
\text { reality, thus } \\
\text { affecting their } \\
\text { daily life. }\end{array}$ \\
\hline
\end{tabular}

Briefly confirm and describe the behavior performance.(If there are several kinds of behaviour, please prioritize them.)

Contact: .Avoid:_Non-activity. 
Table 3. Assessment scale of behaviorextent

\begin{tabular}{|c|c|c|c|c|c|}
\hline 1 & 2 & 5 & 6 & 8 & 10 \\
\hline No harm & Little harm & Light harm & Medium harm & $\begin{array}{l}\text { Significant } \\
\text { harm }\end{array}$ & $\begin{array}{l}\text { Serious } \\
\text { harm }\end{array}$ \\
\hline $\begin{array}{l}\text { Proper } \\
\text { handling of } \\
\text { crisis } \\
\text { events and } \\
\text { maintaining } \\
\text { the } \\
\text { necessary } \\
\text { daily } \\
\text { functions. }\end{array}$ & $\begin{array}{l}\text { Occasional } \\
\text { inappropriate } \\
\text { behaviour, to } \\
\text { maintain the } \\
\text { normal daily } \\
\text { functions } \\
\text { necessary, but } \\
\text { need to work } \\
\text { hard. }\end{array}$ & $\begin{array}{l}\text { Occasional } \\
\text { inappropriate } \\
\text { behaviour, } \\
\text { sometimes } \\
\text { with a decline } \\
\text { in daily } \\
\text { functioning, as } \\
\text { a result of } \\
\text { reduced } \\
\text { efficiency. }\end{array}$ & $\begin{array}{l}\text { There are } \\
\text { inappropriate } \\
\text { coping } \\
\text { behaviour, and } \\
\text { no efficiency, } \\
\text { need to spend a } \\
\text { lot of energy to } \\
\text { maintain the } \\
\text { daily function. }\end{array}$ & $\begin{array}{l}\text { The coping } \\
\text { behaviour of } \\
\text { the help } \\
\text { seeking people } \\
\text { was obviously } \\
\text { beyond the } \\
\text { response of the } \\
\text { crisis events, } \\
\text { and the daily } \\
\text { functional } \\
\text { performance } \\
\text { was } \\
\text { significantly } \\
\text { affected. }\end{array}$ & $\begin{array}{l}\text { Abnormal, } \\
\text { There's no } \\
\text { telling on } \\
\text { themselves } \\
\text { or others, } \\
\text { and there } \\
\text { is risk of } \\
\text { harm. }\end{array}$ \\
\hline
\end{tabular}

Emotion: Cognition:Behaviour: Sum:-

\section{Strategies of crisis intervention}

By actively listening to and using a variety of open-ended questions, help people clarify what they really want to do, test all possible, can choose to produce results, usually refers to the situation is not serious. Consultants should avoid manipulation, domination, preaching and control, to inspire people to establish self-confidence to solve their own.

Cooperative interference. Cooperative consultation is a kind of common problem, which is based on the equal status of the counselor and the help seeker, and the way to solve the problem can be solved. Intervention is a temporary catalyst, which has the function of consultation, consultation and support.

Directive counseling refers to the main decision makers of crisis intervention, and to find out the possible coping mechanism, to make appropriate plans, to guide, to lead and to urge the people to take action. Because of the lack of initiative, they cannot cope with the current crisis.

\section{Acknowledgements}

This research was the result of the College's Level Research Project of Chongqing Police College named Current Situation and Countermeasures of Privacy Security Protection of Personal Data and Information in the Big Data Era in China(Grant No. jy201507). The research was supported by Planning Project of Innovation and Entrepreneurship Training for University Students named Investigation System of Social Mental Changes of University Students (Grant No. 201512757404). It was also supported by Planning Project of Innovation and Entrepreneurship Training for University Students named Evaluation System Research on Evaluation System of Psychological Crisis of Domestic Violence Victims-Based on Evaluation Model of Three-dimensional Screening by Myer (Grant No.201612757351). 


\section{References}

[1]Liu Na, Chen Chen, Cao Yuping, Zhang Yalin, Intergenerational Transmission of Severe Physical ViolencePerpetration in China: Witness Domestic Violence, Chinese Journal of Clinical Psychology, 23(1), pp. 84-87, 2015.

[2]Chen Zhili, Analysis and Enlightenments of Western Theories of Educational Management, Journal of Schooling Studies, 11(5), pp. 38-48, 2014.

[3]Zhou Anping, Issues to Be Addressed by Law Against Domestic Violence: Analysis of the Draft of the Law against Domestic Violence, Collection of Women's Studies, (2), pp. 49-56, 2015.

[4] Xu Jinhai, The Observation and Reflection of Human Nature in Western Education Management Theory, Journal of Tianjin Normal University (Elementary Education Edition), 14(4), pp. 49-56, 2013.

[5]Wang Shuai, The New Development of ContemporaryMainstream Educational Leadership Theory inthe West, Studies in Foreign Education, 40(5), pp. 43-54, 2013. 